\title{
DEVELOPING PANCASILA AND CITIZENSHIP EDUCATION LEARNING MODEL BASED ON CHARACTER EDUCATION THROUGH COMPREHENSIVE APPROACH
}

\author{
Joko Wahono', Intan Kusumawati $2^{*}$, and Ahmad Nasir Ari Bowo ${ }^{3}$ \\ 1,2,3 Universitas Cokroaminoto Yogyakarta, Yogyakarta, Indonesia \\ *intankusumawati1978@gmail.com
}

\begin{tabular}{|c|c|}
\hline Article Info & ABSTRACT \\
\hline $\begin{array}{l}\text { Article history } \\
\text { Received January 14, } 2021 \\
\text { Revised April 6, 2021 } \\
\text { Accepted April 10, } 2021 \\
\end{array}$ & $\begin{array}{l}\text { Education aims to educate and create the nation's future } \\
\text { generation with character. However, problems like brawls, } \\
\text { violence, abuse of narcotics, illegal drugs, and promiscuity } \\
\text { still occur among students. It becomes the concern of }\end{array}$ \\
\hline $\begin{array}{l}\text { Keywords: Character } \\
\text { education; Comprehensive } \\
\text { approach; Pancasila and } \\
\text { Citizenship Education Learning } \\
\text { model }\end{array}$ & $\begin{array}{l}\text { develop their character. The teacher is obligated to develop } \\
\text { Pancasila and Citizenship Education learning models suitable } \\
\text { for good character. Through character education, it hoped } \\
\text { that it would produce a sound generation. The educational } \\
\text { process that gives birth to the expected character is, of } \\
\text { course, gradual. This study aimed to find out the Pancasila } \\
\text { and Citizenship Education learning model for developing } \\
\text { students' character. Research using mixed methods research } \\
\text { with data collection, analysis, and mixing both quantitative } \\
\text { data and qualitative. This study used quantitative and } \\
\text { qualitative approaches in collecting data through interviews } \\
\text { and questionnaires. The results showed that the Pancasila } \\
\text { and Citizenship Education Learning model based on } \\
\text { character education through a comprehensive approach } \\
\text { could develop and shape the students' character, such as } \\
\text { inculcation, modelling, values facilitation, and skill-building. } \\
\text { Through character development, it hoped that good } \\
\text { characters expected to form permanently. }\end{array}$ \\
\hline
\end{tabular}

\section{INTRODUCTION}

The implementation of Pancasila and Citizenship Education Learning is suitable for national education to create a bright and independent generation with Pancasila characteristics. According to Law Number 20 of 2003 article 3 concerning the National Education System, the purpose of national education is to develop students' potential to be human beings who believe in God Almighty, have a noble character, healthy, knowledgeable, competent, creative, independent, and become a democratic and responsible citizen. The learning model of teachers will influence learning in the classroom to deliver lesson plans according to educational goals. Article 37 of Law No. 20 of 2003 states that civic education intended to shape students into good citizens, to make a nation with a Pancasila character. Therefore, Citizenship Education is one of the subjects taught in senior high schools (Sisdiknas, 2003). The role of education is to create the nation's future generation through developing students' critical thinking skills, independence, creativity and problemsolving skills (Zuchdi, 2019). 
Character education forms a person to become a good citizen that cultivates character through the educational process-the developing character through learning in the classroom. Cultivate good attitude-behaviour continuously to shape the soul, body, personality, and education in science and technology (Suwito, 2012). Someone who has a good personality will have mature and accountable decisions (Ramdhani, 2017). An essential role in a family will shape a person's character (Wening, 2012). The results of the previous research, which implies character is vital to shaping people to have good character. However, this research emphasises that character-building needs be comprehensive through education in the family, school, and the wider community. The approach taken is a holistic character-building approach.

Pancasila and Citizenship education will make students be responsible individuals who can obey the rules of society and become good citizens. The insight and awareness to be a good citizen need to develop through education. Pancasila and Citizenship Education aimed to foster understanding and knowledge in terms of Indonesian cultural values that are noble and have an archipelago perspective (Sumarsono, 2005). Pancasila and Citizenship Education Learning facilitates students to develop their skills, knowledge and national insight and form the overall character of students in terms of religion, social, culture, language, and age to become citizens with character. The learning model used is adjusted to the existing conditions according to the circumstances of each student. In this study, Pancasila and Citizenship Education Learning Model Based On Character Education through Comprehensive Approach includes inculcation, modelling, values facilitation, and skillbuilding (Zuchdi, 2019).

\section{METHODS}

This research investigates Pancasila and Citizenship Education Learning implementation in schools based on character education through a comprehensive approach. Research using mixed methods research (Cohen et al., 2018: 31) with data collection, analysis, and mixed quantitative and qualitative data. This research conducted to determine Pancasila and Citizenship Education learning in schools using a comprehensive approach in learning. The stages of mixed methods research (Cohen et al., 2018: 48) start from finding goals research, research questions, quantitative and qualitative data collection, data analysis, and finally, making a research report. This study uses data analysis techniques qualitatively and quantitatively. This study used qualitative and quantitative data analysis techniques. The research instruments used to collect the data were interview and questionnaire. The subjects were 5 schools in the Special Region of Yogyakarta, namely SMA N 2 Sleman, SMA N 1 Sentolo Kulon Progo, SMA N Patuk Gunung Kidul, SMA N 1 Banguntapan Bantul and SMA Muhammadiyah 2 Yogyakarta. 


\section{RESULT AND DISCUSSION}

\section{RESULT}

Character education in schools in Pancasila and civic education subjects that contain moral values is crucial for forming student character. By developing learning models for Pancasila and civic education subjects packaged in an attractive, comprehensive manner and implementing educational synergies in families, schools, and communities, education will be successful. Character formation is through a process and through until a person's character is formed and attached to a person. Character education is a conscious effort to realise personal virtues as individuals and communities (Lickona \& Matters, 2012). Character education can affect the personality and behaviour of a person to have a better life (Flanagan et al., 1993). Formal education in schools can instil values among students. Pancasila and Citizenship Education is one of the subjects that provide and instil character values among students. Character education carries the same goal of instilling something excellent and praiseworthy (Dalmeri, 2014). Education of values, social attitudes, knowledge and skills are the core competencies of Pancasila and Citizenship Education subjects as a medium to instil moral values that have the noble character for them. Moral education is a kind of human experience in their life (Hamlin et al., 2007). Noble morals can learn to form morals and understand in one's life, through Pancasila and Citizenship education, to develop morals, reduce and fortify reprehensible behaviour among students, and create generations with noble character. Character education carries the same goal, namely to instil something excellent and praiseworthy. Through this approach, they expected to develop character education based on Pancasila and Citizenship Education learning models. The educational approach used to produce a character as a complete union.

\subsection{PANCASILA AND CITIZENSHIP EDUCATION LEARNING}

Pancasila and Citizenship education learning expected to contain moral values that can manifest in the form of behaviour called character (Apriono, 2009). This learning must contain moral values to learn how students behave in their daily lives and social lives. They expected to gain knowledge and skills in socializing in their social life. Article 1, paragraph 19 of Law Number 202003 about curriculum and learning devices regulates the learning guidelines in the classroom. Pancasila and Citizenship education learning in 2013 curriculum expected to present learning contextually and relate to actual condition (Sisdiknas, 2003). Pancasila and Citizenship education teachers who are creative, innovative, and open can identify problems and ways to find problem-solving.

Pancasila and Citizenship education taught using a scientific approach in every lesson in Curriculum 2013 (Samsuri, 2011). The teacher is required to use appropriate teaching methods and models so that educational goals are achieved. This subject aimed to form Indonesian citizens with the character as the foundation of the State, namely Pancasila and the Preamble of 1945 Constitution (Ihsan, 2017). This subject can develop morals and values 
to improve the quality and personality under the National Education System Law (Syam, $2011)$.

\subsection{CHARACTER BUILDING}

Building good citizens can be realized when character and virtue are related (Arthur \& Harrison, 2012). Thus, a good character will be a good citizen, and people with character become good citizens (Sim \& Low, 2012). Character education can be obtained through watching films that show good things (Russell III \& Waters, 2013). Character education should teach to have personal and social roles as citizens in society (Zuhdi, 2010). Character education is a deliberate effort in social life among societies to form an optimal character (Lickona, 1991). Characters made from concepts, attitudes and behaviours can produce a character for their personal and social life as citizens. The values of character education developed include three components: diversity, independence, and decency (Ratna, 2007). There are also three main components in teaching the values of character education, namely moral knowing, moral feeling, and the most important thing is moral action (Lickona, 1991). Character education contains moral education, containing the values of knowledge, social skills and religious values.

Education is a process of a long journey to a better and more dignified direction. Character is an issue that is interesting to study and find the solution. The country can achieve its goal by implanting the citizens with character. A country that does not have good character-building will become a country that will decline in various ways. The development of educational technology is the most influential factor in education. The philosophical foundation in character development becomes the direction for character development itself in the education process. Education is a conscious effort to build a person's character towards a better approach (Kusumawati, 2016).

Religion-based character education is also a conscious effort made by someone to have good character, behaviour and character in their daily activities (Ratna, 2007). Character values in religious teachings are noble values. Religion is a guideline for humans to carry out their worship activities as human beings. The basis of morality should be realized or applied in religious teachings. The development of Indonesian's character, especially among students, declines even though they practice their religion without any internalization of the value in daily life. The role of the teacher is significant in teaching character education in schools. Good character education can provide knowledge and skills to bring out characters with good moral and social values. The development of a person's moral character does not move to an endpoint where moral principles are more victorious than non-moral demands (Hafidhuddin, 2018).

Moral character education can inadvertently create a bond between friends who share knowledge or motivation about negative behaviour and invoke their friends' behaviour rather than prevent it (Kusumawati, 2017). Good behaviour can transmit to others just like 
lousy behaviour can affect others. Character education should grow students to behave both in the school, home, and community in a suitable manner because it teaches people's lives in the family, school, and society. Character education teaches the noble values in Pancasila as the basis of the Republic of Indonesia, such as the values of honesty, responsibility, cooperation, hard work, cooperation, and nationalism. Character education needs to continuously nurture and develop so that someone has a good character. Thus, the skills are needed to create this character so that the character is wholly implanted in them.

\subsection{THE COMPONENTS OF CHARACTER}

The components consist of three components of a good character. The first, moral knowledge that learners have about what moral understanding and meaning within knowledge, such as moral awareness, knowledge of values and ways to behave and do good things. The second, moral feeling that comes from the inner energy to act. The conscience plays a role in the component of values, how a person can feel what others feel, empathize with how the truth feels and can control feelings. Third, moral action that a person is required to do good deeds through his actions in real life without external coercion becomes a habit (Lickona, 1991). An exemplary component of character values can be described in Figure 1.

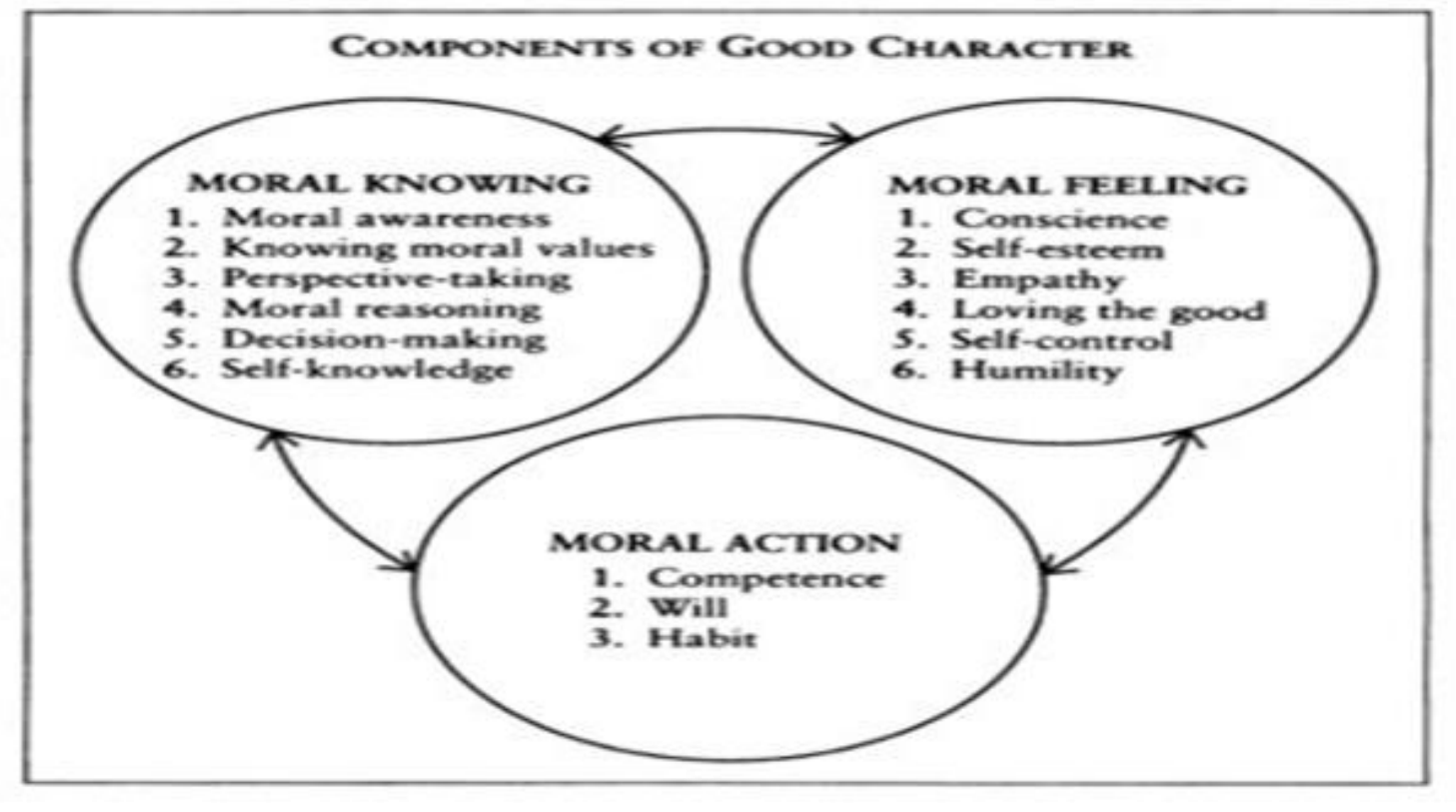

Figure 1. Components of good character (Lickona, 1991)

The three components of the character above will fulfil if implemented. To achieve those three components, the desire to implement those should exist. Thomas Lickona stated that there are seven central character values in students which include: (1) sincerity or honesty expected that students have a heart that can touch their conscience and behave according to their conscience, (2) compassion expected that students have compassion, like fellow human beings with one another, and has a sense of humanity, also to animals or plants as well as should treat them well, (3) courage expected that students have the 
courage to take attitudes and decisions by considering values, (4) love affection or kindness, a student should have control of affection for anyone, (5) self-control, a student must have control over emotions and attitudes in every action, (6) cooperation or cooperative attitude, students are required to work with groups in work either in the classroom or outside the classroom and in the social life of the community, and (7) hard work or diligence, students should have great enthusiasm in every effort to solve problems in protecting schools and communities. Those seven-character values expected to be taught in Pancasila and Citizenship education learning based on character education to develop students when they learn (Lickona, 1991).

\subsection{COMPREHENSIVE APPROACH}

A Comprehensive Approach is an approach that consists of orientation, exploration, deepening and inference (Nucci \& Narváez, 2014). The approach starts from the introduction, that is, the core activities by searching and finding, exploring and concluding the end of the lesson. Therefore, students can have the character expected by the learning objectives of Pancasila and Citizenship education. A comprehensive approach to character education includes inculcation, modelling, and facilitation of values and development of soft skills (Lickona, 1991).

\section{DISCUSSION}

This research contributes to the character development of students. Student character will form through daily processes in every lesson at school, which includes knowledge and skills. Students' daily skills will develop according to the experiences they experience. Students know what honesty, discipline, cooperation, and responsibility mean, but students can already apply them in their daily lives, be it in school, family, and society. The development of character education based on Pancasila and Citizenship education Learning model was conducted by researchers in five schools located in the Special Region of Yogyakarta, called a city of students, whose vision is to improve human dignity in Yogyakarta through "Panca Mulia" (the five glories), namely: (1) Realizing the improvement in the quality of life livelihoods of a just and civilized society, through capacity and skills of the competitive human resources of Yogyakarta, (2) Realizing the improvement in the quality and diversity of community economic activities, and strengthening economy based on local resources (uniqueness of economic territory) for the growth of community income as well as equitable economic growth, (3) Realizing the improvement in the harmony of life together both in the community and in the bureaucracy on the basis of tolerance, consideration, politeness, and togetherness, (4) Realizing democratic governance and behavior, and (5) Realizing dignified behavior of the civil servants who run the government on the basis of upholding integrity values that uphold honesty and conscience such as feeling ashamed and guilty when committing deviations such as corruption, collusion, and nepotism. The implementation of 
character education in schools is not a separate subject, nor is it an additional standard of competence and basic competence but can integrate into existing subjects, selfdevelopment, school culture, and local content (Judiani, 2010).

Someone who educated should be a wise person in all activities in his life (Megawangi, 2010). A person's character will continue to develop when a person is willing to learn to process and continuously strive towards good self-development and become a strong person and have the character of Pancasila. However, there are still undocumented assessments of student attitudes in a learning activity at school, such as teacher's lack of understanding to implement character education and no synchronization on realizing the education between at school and home (Darmayanti \& Wibowo, 2014). World globalization resulted in both positive and negative impacts for every Indonesian citizen (Kurniawan, 2015). It is necessary to handle all forms of negative implications regarding the flow of globalization by providing character education (Dalyono \& Lestariningsih, 2016).

Everyone should be responsible for their character. Character education is not only sufficiently conveyed in schools but should apply in daily life (Gunawan, 2012). The pros and cons of a person's character are not only seen briefly but as a whole. Character education needs serious handling from various parties, starting from within the family, school, and community. Principally, character education is an effort that is carried out consciously and responsibly with an honest, independent, sincere and sincere heart by various school personnel, from school principals, teachers, employees and students, even those who carried out together with other people. Parents consisting of father, mother, brother and community members were to help children and adolescents to become or have a caring nature (Hendriana \& Jacobus, 2017).

A child with good character does not mean that he has never done negative things, but this behaviour is still within reasonable limits (Suwito, 2012). A child sometimes still imitates the people around him. The behaviour of children who sometimes commit reasonable delinquency can still be corrected in the form of a warning or wise advice and motivation from the environment to behave well, politely and with character. Individuals with good character can make decisions, be ready to take responsibility for any consequences of their decisions, become good individuals, and need conscious self-awareness (Ramdhani, 2017). A person's character can be conditioned socially (Riesman et al., 2020). A person can influence another. An alternative to character education is the ethics of caring. The ethics of caring can be seen as fundamentally relational, not individual in virtue ethics, and the ethics of caring are more indirect than character education (Noddings, 2002).

In recent years, "character education" has emerged in the United States as the primary term for schools to implement moral, ethical and civic values and establishes 11 principles to guide schools in planning their character education. These include the issues such as; core ethical values and their justifications, character definitions, a comprehensive and deliberate 
approach to developing good character, developing schools as caring communities, the relationship between character education and academic curriculum and evaluation (Lickona, 1996). Even though character education is not new, scientific studies on its effectiveness have only been implemented sporadically over the last thirty-five years. Most of the applications, therefore, character education is not informed by a scientific knowledge base (Berkowitz \& Bier, 2004).

The establishment of civic education as a compulsory subject had recently been carried out along with government policy to 'boost character education. Identification has a vital role in forming and strengthening primary character (Berkowitz \& Bier, 2004). The development of this learning model through three stages, namely a preliminary study, where the researcher and the school discussed the research design and data mining related to the implementation of Pancasila and Citizenship education learning so far, then the researcher and the teacher-designed Pancasila and Citizenship education learning model using the comprehensive approach and testing the model tested after. In this study, the following research results obtained:

In this study, the school used the 2013 curriculum in the implementation of learning. The guided curriculum used meant that the curriculum was half-open and half-closed. Teachers' roles have determined in the curriculum, but they still give the possibility to develop further in the classroom. In 2013 Curriculum Development, in this study, about 60\% emphasized the balance of knowledge, attitudes, and skills. Meanwhile, only $40 \%$ used a scientific approach in learning.

The curriculum implemented using an active learning process; teachers performed their duties as facilitators and motivators by packaging subjects to be more meaningful in everyday life with an integrative thematic learning model and a scientific approach. The weaknesses in the 2013 curriculum suitable for use in schools that are advanced and the teachers have high enthusiasm for learning, people who are educated and have equal abilities and facilities, and telecommunications and transportation infrastructure evenly distributed so as not to hinder the process and use of the National Examination (UN) as an evaluation of the standard of the active student learning process.

Pancasila and Citizenship education learning model for developing students' character in the class used online methods: (1) Cooperative Learning Model. The cooperative learning model is a learning activity in groups to help each other construct concepts and solve problems or inquiries (Purnamasari, 2014; Putra, 2018); (2) Problem Solving Method. The problem-solving learning model is one approach in group learning and requires simple abilities and can be done by all students asking these questions according to the material they are learning (Putra, 2018); (3) Problem Solving Method. The method of understanding the problem or problem Solving itself is the lesson material by making the problem a starting point for discussion to be analyzed and synthesized to find solutions or answers by students. 
On the other hand, problem-solving also defined as a learning model by emphasizing solving a problem logically (Anwar, 2017); (4) Habitual and Exemplary Methods. Exemplary and habituation in education were needed because psychologically, students imitate more behaviour or figures they idolize, including their teachers. Habit is no less critical in learning activities. Every knowledge or behaviour obtained by habituation is complicated to change or eliminate, advantageous in educating (Manan, 2017).

The strategy used by teachers in PPKn learning is to use learning strategies. Learning strategies (direct change) such as lecture methods, didactic questions, precise application, exercises and exercises, and maps. Formulation of indirect learning strategies (indirect instruction) such as students making observations, research, describing inferences based on data, or hypothetical messages. The Direct Learning Strategies (direct instruction) such as lecture methods, didactic questions, explicit teaching, exercises and exercises, and demonstrations. The teaching method in Pancasila and Citizenship education developed student character in the classroom was $80 \%$ interactive learning and $20 \%$ direct learning. Learning through experience was $20 \%$ where the teacher gave independent assignments that could be seen in Figure 12 in the form of $80 \%$ assigning homework and $20 \%$ through giving assignments in the form of writing. Teachers giving student learning assignments experienced $60 \%$ by playing roles while $40 \%$ using observation or survey field trips, amounting to $40 \%$.

In providing indirect learning to students related to character development in the form of $80 \%$ using problem-solving methods and only $20 \%$ using the case study method. In direct learning to the students associated. The with character development, namely by using demonstrations of $40 \%$, explicit teaching of $40 \%$ and lectures of $20 \%$. Learning about student character development in the form of discussion was $40 \%$, role-playing was $40 \%$, and cooperative learning was $20 \%$-namely the moral components of knowing moral feeling and moral action. From the results of research conducted by researchers at five schools located in the Yogyakarta Special Region, it can conclude that in the development of characterbased Pancasila and Citizenship education learning models so far have used a comprehensive approach, namely inculcation, modelling, facilitation, and development student skills (skill-building).

\section{CONCLUSION}

The results of the research conducted indicate that character formation can form through habits. With Pancasila and civic education learning models in schools, students' character formed through communication skills, cooperation skills, friendly or inferior attitude skills, and adapting skills to the environment. Student character will form through character development. A synergy of family, school, and community education is needed. Character building goes through stages and processes. Requires a firm commitment so that the 
character that expected will form. To be someone of good character and to be a good citizen. The research results at five schools in the Special Region of Yogyakarta can conclude that character-based Pancasila and Citizenship education learning models have used a comprehensive approach, including exemplary (modelling), facilitation, and skill-building.

\section{ACKNOWLEDGMENTS}

Thank to the principal who has granted research permission as well as teachers and employees of SMA N 2 Sleman, SMA N 1 Sentolo Kulon Progo, SMA Negeri Patuk Gunung Kidul, SMA N 1 Banguntapan Bantul and SMA Muhammadiyah 2 Yogyakarta who have collaborated in the smooth running of this research. Hopefully this research can be useful for scientific development and skills development. We would like to thank the Directorate of Research and Community Service, the Directorate General of Empowering Research and Development of the Indonesian Ministry of Research Technology and Higher Education (Direktorat Riset dan Pengabdian Masyarakat, Direktorat Jenderal Penguatan Riset dan Pengembangan Kementerian Riset, Teknologi, dan Pendidikan Tinggi Republik Indonesia) for the financial support for the research and publication of this article under the Grant number 081/SP2HMAD/LT/DRPM/2020.

\section{REFERENCE}

Anwar, N. N. (2017). Meningkatkan pemahaman siswa pada pembelajaran pkn dengan penggunaan metode pemecahan masalah. Syntax Literate; Jurnal IImiah Indonesia, 2(3), 99-112.

Apriono, D. (2009). Advance Organizer: Konsep, Komponen Model, dan Implementasi dalam Pembelajaran PPKn. Jurnal Ilmu Pendidikan.

Arthur, J., \& Harrison, T. (2012). Exploring good character and citizenship in England. Asia Pacific Journal of Education, 32 (4), 489-497.

Berkowitz, M. W., \& Bier, M. C. (2004). Based on character education. The Annals of the American Academy of Political and Social Science, 591 (1), 72-85.

Cohen, L., Manion, L., \& Marrison, K. (2018). Research methods in education, eighth edition, Rotledge. (Eighth edi). Routledge.

Dalmeri, D. (2014). Pendidikan Untuk Pengembangan Karakter (Telaah terhadap Gagasan Thomas Lickona dalam Educating For Character). Al-Ulum, 14 (1), 269-288.

Dalyono, B., \& Lestariningsih, E. D. (2016). Implementasi penguatan pendidikan karakter di sekolah. Bangun Rekaprima: Majalah Ilmiah Pengembangan Rekayasa, Sosial Dan Humaniora, 3(2, Oktober), 33-42.

Darmayanti, S. E., \& Wibowo, U. B. (2014). Evaluasi program pendidikan karakter di sekolah dasar Kabupaten Kulon Progo. Jurnal Prima Edukasia, 2 (2), 223-234.

Flanagan, O. J., Rorty, A. O., \& Rorty, A. (1993). Identity, character, and morality: Essays in 
moral psychology. MIT press.

Gunawan, H. (2012). Pendidikan karakter. Bandung: Alfabeta, 2.

Hafidhuddin, D. (2018). Konsep Pendidikan Karakter Berbasis Pendidikan Agama. Ta'dibuna: Jurnal Pendidikan Islam, 1 (2).

Hamlin, J. K., Wynn, K., \& Bloom, P. (2007). Social evaluation by preverbal infants. Nature, 450 (7169), 557-559.

Hendriana, E. C., \& Jacobus, A. (2017). Implementasi pendidikan karakter di sekolah melalui keteladanan dan pembiasaan. JPDI (Jurnal Pendidikan Dasar Indonesia), 1 (2), 25-29.

Ihsan, I. (2017). Kecenderungan Global dalam Proses Pembelajaran Pendidikan Pancasila dan Kewarganegaraan di Sekolah. JPK (Jurnal Pancasila Dan Kewarganegaraan), 2(2), 49-58.

Judiani, S. (2010). Implementasi pendidikan karakter di sekolah dasar melalui penguatan pelaksanaan kurikulum. Jurnal Pendidikan Dan Kebudayaan, 16(9), 280-289.

Kurniawan, M. I. (2015). Tri pusat pendidikan sebagai sarana pendidikan karakter anak sekolah dasar. PEDAGOGIA: Jurnal Pendidikan, 4(1), 41-49.

Kusumawati, I. (2016). Landasan Filosofis Pengembangan Karakter Dalam Pembentukan Karakter. Academy of Education Journal, 7(1), 1-15. https://doi.org/10.47200/aoej.v7i1.342

Kusumawati, I. (2017). Pengembangan Karakter Siswa Raudlatul Athfal Berbasis Pendidikan Agama Islam. As-Sibyan: Jurnal Pendidikan Anak Usia Dini, 1 (02), 139-1 48.

Lickona, T. (1991). Educating for the character (New York, Bantam). MCCI ET NAN, BE (1992) Schools and the Shaping of Character: Moral Education in America, 525-543.

Lickona, T. (1996). Eleven principles of effective character education. Journal of Moral Education, 25(1), 93-100.

Lickona, T., \& Matters, C. (2012). How to help our children Develop Good Judgement, integrity, and other essential Virtues. Terjemahan. Jakarta: PT. Bumi Aksara.

Manan, S. (2017). Pembinaan Akhlak Mulia Melalui Keteladanan dan Pembiasaan. Jurnal Pendidikan Agama Islam-Ta'lim, 2(1), 49-65.

Megawangi, R. (2010). Pengembangan program pendidikan karakter di sekolah: pengalaman sekolah karakter. Jakarta: Indonesia Heritage Foundation (IHF).

Noddings, N. (2002). Educating moral people: A caring alternative to character education. ERIC.

Nucci, L., \& Narváez, D. (2014). Handbook of moral and character education. Routledge.

Purnamasari, Y. (2014). Pengaruh model pembelajaran kooperatif tipe teams games tournament (TGT) terhadap kemandirian belajar dan peningkatan kemampuan penalaran dan koneksi matematik peserta didik SMPN 1 kota Tasikmalaya. Jurnal Pendidikan Dan Keguruan, 1 (1), 209664.

Putra, N. L. J. (2018). Upaya Meningkatkan Prestasi Belajar PKn pada Materi Sikap Positif 
terhadap Norma melalui Model Pembelajaran Problem Solving. Jurnal IImu Pendidikan (JIP) STKIP Kusuma Negara, 9(2), 49-64.

Ramdhani, M. A. (2017). Lingkungan pendidikan dalam implementasi pendidikan karakter. Jurnal Pendidikan UNIGA, 8(1), 28-37.

Ratna, M. (2007). Character Parenting Space, Menjadi Orang Tua Cerdas Untuk Membnagkitkan Karakter Anak. Bandung: Mizan Media Utama.

Riesman, D., Glazer, N., \& Denney, R. (2020). The lonely crowd: A study of the changing American character. Veritas Paperbacks.

Russell III, W. B., \& Waters, S. (2013). "Reel" Character Education: Using Film to Promote Global Citizenship. Childhood Education, 89(5), 303-309.

Samsuri, S. (2011). Kebijakan Pendidikan Kewarganegaraan Era Reformasi di Indonesia. Cakrawala Pendidikan, 2, 78213.

Sim, J., \& Low, E. L. (2012). Character and citizenship education: Conversations between personal and societal values. Asia Pacific Journal of Education, 32 (4), 381-394.

Sisdiknas, U.-U. (2003). Undang-Undang RI No. 20 Tahun 2003. Jakarta: Sinar Grafika.

Sumarsono, S. (2005). Dkk. In Pendidikan Kewarganegaraan. Jakarta: Gramedia Pustaka Utama.

Suwito, A. (2012). Integrasi Nilai Pendidikan Karakter ke dalam Mata Pelajaran Pendidikan Kewarganegaraan di Sekolah Melalui RPP. CIVIS, 2 (2/Juli).

Syam, N. (2011). Peningkatan Kualitas Pembelajaran Pkn di Sekolah Dasar melalui Model Pengajaran Bermain Peran. Perspektif IImu Pendidikan, 24 (XV).

Wening, S. (2012). Pembentukan karakter bangsa melalui pendidikan nilai. Jurnal Pendidikan Karakter, 1 .

Zuchdi, D. (2019). Humanisasi pendidikan. Bumi Aksara.

Zuhdi, D. (2010). Pendidikan Karakter dengan pendekatan komprehensif. Yogyakarta: UNY Press. 